\title{
Issues and options in high country farming 2. Evaluating technical options
}

\author{
D. SCOTT $^{1}$ and W. WILLIAMS ${ }^{2}$ \\ ${ }^{1}$ AgResearch, PO Box 60, Lincoln \\ ${ }^{2}$ AgResearch, Grasslands Research Centre, PB 11008, Palmerston North
}

\begin{abstract}
An assessment is made of the factors influencing high country pastoral production, their degree of science validation and an estimate of their effect on total run production. Fertiliser, and introduced pasture species suited to the rate of fertiliser input are the main avenues for increased biological productivity; and stock nutrition and breeding as the means of producing a specialised product.
\end{abstract}

Keywords: economics, fertiliser, high country, pasture species, sheep, stock

\section{Introduction}

This paper identifies the aspects considered and the technological components required in high country farming, their present use, and our assessment of their importance in total farm management, and the degree to which they are supported by scientific investigation. These are given under the general headings of fertilisers, forage production, stock husbandry, weeds and pests, infra-structure, resource management, and economic management. By technology we mean both procedures and techniques, such as how to do a mulesing operation to limit fly-strike, as well as physical products like fertilisers, drenches and tractors. A larger and more fully referenced version of the paper is available on request.

\section{Resource and allocation}

South Island high country runs vary greatly in altitude, topography, rainfall, snow fall, soils and accessibility, and are at the low temperature extreme of New Zealand agriculture. Large variations occur within individual runs and strongly interact with the various technological options. The art in farming is, for the particular run, to integrate these variations in land classes, their site factors and the various technological options into viable farming systems. This involves decisions on the type of enterprise intended (e.g., sheep for wool or meat, or cattle); the stock type, number and age structure; paddock types and number; and the infra-structure required. This paper will concentrate on the technical components that can influence those decisions, rather than the more difficult problem of how to integrate them. Site information for particular runs and blocks is now generally available, to at least the first approximation, in the general national inventories of topography, soils, climate, erosion, land classes, etc.

\section{Fertilisers}

Table 1 Fertiliser technologies for high country pastoral farming, their present use, potential impact and research support.

$$
\begin{array}{cl}
\text { Managed or used } & \text { Research support } \\
\mathrm{UU}=\text { widely used } & \mathrm{RR}=\text { well researched } \\
\mathrm{U}=\text { occasionally used } & \mathrm{R}=\text { moderately researched } \\
\mathrm{u}=\text { rarely or not used } & \mathrm{r} \text { = largely unstudied }
\end{array}
$$

\begin{tabular}{lllll}
\hline Technology & Use & \multicolumn{3}{c}{ Potential Impact } \\
& & Low & Mod. & High \\
\hline Type and rates & & & & \\
S & UU & & & RR \\
P & UU & & & RR \\
N & U & & R & \\
lime/acidity & U & R & & \\
K & U & R & & \\
Mg & U & r & & \\
Mo & UU & & RR & \\
\hline
\end{tabular}

\section{Sulphur (S) and Phosphorus (P)}

Pasture development in the high country is based mostly on introduction of fertilised legumes, to fix nitrogen, to grow grass. Early studies showed that $\mathrm{S}$ was equally or more deficient than $\mathrm{P}$ for legume growth in the drier areas of the high country. A general relationship between increasing rainfall, increasing superphosphate rate requirements, but decreasing $\mathrm{S}: \mathrm{P}$ ratio for both establishment and maintenance of pastures is now well established. In general there is a 4 to 5 -fold increase in potential pasture production in the high country with application of $\mathrm{S}$ and $\mathrm{P}$ fertilisers (yellow-grey earth naturally fertile soil x1.4 for legumes; yellow-brown earth $\times 4.1$ ).

\section{Nitrogen (N)}

Direct use of $\mathrm{N}$ fertilisers has been possible since the 1970s. Mostly this has been used for enhancing grass and legume establishment, e.g., for grass establishment 
if rates with the seed do not exceed $25 \mathrm{~kg} \mathrm{~N} / \mathrm{ha}$. However, none of the trials have run long enough to show whether the increased grass seedling growth can persist long enough until the $\mathrm{N}$ cycle can be built up by the accompanying legumes, or whether $\mathrm{N}$ fertiliser jeopardises long-term legume rhizobia relationships.

There is a very large response of established stands to $\mathrm{N}$ fertiliser, e.g., up to an 18 -fold increase in grass yields without accompanying legumes. The productivity of $\mathrm{N}$-fertilised mixed pasture may be twice that of legume-based pastures. Though more costly, the potential yield of $\mathrm{N}$-fertilised swards may be justified as special purpose pastures for critical feed periods. Strategic use of $\mathrm{N}$ is therefore given a moderate impact rating.

\section{Other fertiliser}

The increase in soil acidity with pasture development is an increasing concern. There is some responses to liming. However the transport cost, for high liming rates, do not make it a cheap fertiliser for most high country situations. The earlier world and New Zealand literature suggest that the main response to lime has been increasing local soil $\mathrm{pH}$ to facilitate legume rhizobia infection. In this era this is more efficiently done with legume seed coating. There have been no reported responses to potassium or magnesium fertiliser except in revegetation of eroded sub-alpine subsoils. Molybdenum is required for legumes in the higher rainfall soils. There are no indications of other micronutrient deficiencies for plants.

\section{Forage production}

\section{Pasture management}

For the high country, pasture can be usefully subdivided into three categories:

- modified tussock grassland ranging from slightly modified tall tussock to the depleted hieracium deserts of some drier zones;

- oversown modified tussock grassland with introduction of pasture species, particularly legumes, into existing grassland;

- fully developed improved grassland after cultivation and sowing (generally special purpose pastures).

Management of oversown and developed grasslands is rated as having high impact (Table 2) on present high country farming, as $80 \%$ of stock are grazed on the $20 \%$ of the land that has been so developed. For these oversown and developed grasslands grazing management guidelines are broadly similar to those for developed pastures in easier environments. However for the high country there are shorter periods of pasture growth, so that assumption of the continuity in feed production in the rotational grazing has to be modified, and there is a greater need to consider the carry-over of standing feed between periods. The loss in feeding value of standing herbage is not well understood.

Table 2 Forage production technologies for high country pastoral farming, their present use, potential impact and research support. Coding as in Table 1.

\begin{tabular}{|c|c|c|c|c|}
\hline \multirow[t]{2}{*}{ Technology } & \multirow[t]{2}{*}{ Use } & \multicolumn{3}{|c|}{ Potential Impact } \\
\hline & & Low & Mod. & High \\
\hline \multicolumn{5}{|l|}{ Pasture management } \\
\hline modified & UU & & $r$ & \\
\hline - burning & $\mathrm{u}$ & & $\mathrm{R}$ & \\
\hline oversown & UU & & & $\mathrm{R}$ \\
\hline developed & UU & & & $\mathrm{RR}$ \\
\hline pest/ diseases & $\mathrm{u}$ & $r$ & & \\
\hline \multicolumn{5}{|l|}{ Pasture establishment } \\
\hline method & UU & & $\mathrm{R}$ & \\
\hline herbicide & $U$ & & $\mathrm{R}$ & \\
\hline drill type & UU & & $\mathrm{R}$ & \\
\hline species & UU & & & $\mathrm{RR}$ \\
\hline cultivar & $U$ & & $\mathrm{R}$ & \\
\hline rhizobia coating & UU & & & $\mathrm{RR}$ \\
\hline seed treatment & & $\mathrm{R}$ & & \\
\hline \multicolumn{5}{|l|}{ Winter feed } \\
\hline native/modified & UU & & & $r$ \\
\hline hay/silage & UU & & & $\mathrm{R}$ \\
\hline special purpose & $U$ & & & $\mathrm{R}$ \\
\hline \multicolumn{5}{|l|}{ Pasture weed control } \\
\hline hieracium & $U$ & & $\mathrm{RR}$ & \\
\hline wilding tree & $\mathrm{u}$ & & $\mathrm{R}$ & \\
\hline briar & $U$ & & $\mathrm{R}$ & \\
\hline matagouri & $U$ & & $\mathrm{R}$ & \\
\hline cheat grass & $\mathrm{u}$ & & $r$ & \\
\hline \multicolumn{5}{|l|}{ Pasture pest control } \\
\hline rabbit & UU & & & RR \\
\hline deer & UU & $\mathrm{R}$ & & \\
\hline others & UU & $r$ & & \\
\hline opossum & $\mathrm{U}$ & & $\mathrm{R}$ & \\
\hline
\end{tabular}

The long winter period of non-growth makes the provision of winter feed a highly important aspect of high country farming, and high rating is given to pasture production technologies to supply it. In the high country, stock body weight can only be maintained over the winter period. Priority is given to supplementing hoggets, then ewes, with wether supplementation still uncommon. Big bale hay is now the prevalent form of stored forage. Silage is uncommon, partly because of its weight and distance between harvesting and feeding out areas on high country runs. Supplementation with grain is uncommon.

Because of the shift in grazing from modified tussock grassland to oversown and developed pastures, the impact of management of modified tussocks grassland has been rated as moderate, even though historically it has been high. In spite of the long history of use, the 
pasture management requirements of modified tussock grasslands have not been thoroughly researched. Most guidelines have concerned the extremes, e.g., excessive loss of ground cover and soil erosion indicating overgrazing, or dense, inpenetratable grass and scrub indicating a need for burning.

Except for rabbits, technologies for pasture pest and weed control have a moderate rating for management of modified and oversown tussock grasslands.

Rabbits are in direct competition with stock and are a continuing problem. Deer have changed in status since domestication. Of local importance are geese, thar, wallaby, chamois, and hare. Opossum are a health problem (tuberculosis) to domestic stock rather than as a feed competitor. Other pasture pests are the native grass grub and porina. The major present high country weeds are hieracium species. Others with more limited effect on forage availability and stock access are matagouri, briar, scrub, wilding trees and cheat grass. A few are poisonous (tutu and St John's wort).

Tussock and other native grasses are the major component of modified tussock grassland and are a variable component of the partly developed grasslands. The tussocks dominated the original grassland in terms of stock access and shelter. While only partly palatable in the mature state, their regrowth after burning was palatable. However, with the possible exception of $\mathrm{Poa}$ colensoi, tussocks were not major diet species, that role being filled by smaller associated species. Their virtues relate to cultural, nature conservation, and agricultural shelter values. Few, with the exception of Poa colensoi, would justify development of technologies for their reintroduction for purely agricultural purposes.

\section{Species selection and establishment}

For species selection and establishment of oversown and developed pastures the high impact considerations are site characterisation, fertiliser, choice of pasture species, and rhizobia coating of legume seed (Tables 1 and 2).

One of the themes of recent investigations is that development options depend on where a particular site falls within the environmental gradients of moisturerainfall; temperature-altitude, aspect and slope; the natural soil fertility and depth; and the affordable types and levels of fertiliser possible.

A second theme is that though there are many different pasture species, only one or a few species suit each particular combination of factors. In particular there should be a good match between the pasture species and the soil fertility level used.

In development of pastures, the primary response is to fertiliser, with main initial increases from the sown rhizobia-coated legume component. The increase of the more desirable winter-feeding characteristics of grasses must generally await the soil fertility build-up of legumedominant phase. Experience would indicate that adequate time must be allowed for initial establishment before first use, and that pastures may take a decade to develop to their full potential. The desirable pasture management requirements are short sharp grazing followed by adequate regrowth periods, and the maintenance of fertiliser inputs.

The pasture species best suited to the high country are mostly those that have been used and developed in other areas, e.g., red clover, white clover, cocksfoot, and lucerne. Alsike clover is an exception in being one of the main clovers used in high country development, but seldom used elsewhere in New Zealand.

The general advice is to get the species right for the particular environmental combination before seeking the finer adaptation of cultivar differences. G50 alsike has been the only cultivar bred specifically for the high country, though there was a large high country component in the development of Maku lotus, Goldie birdsfoot trefoil and Hakari brome grass. Available cultivars in some species have been ranked for their adaptation to the high country, e.g., within red clovers Pawera $>$ Hamua $>$ Turoa; and within cocksfoots Kara $>$ Sarborto $>$ Apanui $>$ Wana.

Besides improved pasture species, a large number of naturalised species spread and increase in modified and oversown tussock grassland, e.g., browntop, sweet vernal, sheep's sorrel, haresfoot clover. There has been a $20-30 \%$ increase in the species biodiversity of the high country from these introduced naturalised species.

There has been a long and continuing effort of testing of plant introductions from other parts of the world for their suitability to the New Zealand high country. We estimate that since the $1930 \mathrm{~s}, 30-50$ different lines per year have been introduced and tested. Only a small number show sufficient potential for subsequent development. Birdsfoot trefoil, perennial lupin, tall oat grass, salt bush and caucasian clover are recent successful examples. Selection is for persistence and soil conservation as well as production.

\section{Stock husbandry}

High country run production is predominantly sheep for wool. This has been determined principally by the domestic animal which thrived best in those environments, which was the Merino, with its high-value fine wool.

The general view of the world sheep industry is that during the next decade prices for meat will be more important than wool for crossbreeds, but that a premium for fine wool will be retained. For the high country it 
would imply the need for a continued emphasis on low micron, high-value wool production, giving a continued emphasis on wool quality production ahead of fecundity.

Accordingly, management to improve fleece weights and reduce fibre diameter will continue. Wool yields, fibre diameter and wool classing have high impact ratings, along with selection-breeding, nutrition, selenium supplementation and feed budgeting, to achieve these targets (Table 3 ). In addition more growers will adjust their breeding and husbandry practices to produce wool with the individual specifications of particular processors and manufacturers.

Wool growth in Merinos is largely a function of strain and the level of feeding. Sheep buffer short-term fluctuations in nutrition by mobilising body reserves. The desirable management objective is for an even forage supply for sheep with an adequate level of body reserves, e.g., Merino hoggets of 30-35 kg liveweight by the first winter, reaching $50 \mathrm{~kg}$ by mating as 2 tooths in the second autumn. This requires feed budgeting, mineral supplementation and disease and parasite control.

Research has focused on ewe, lamb and hogget growth but has largely ignored wethers, even though they are important. The trend is towards emphasis on per animal production rather than per hectare production.

There has been only one trial that shows the effects of stocking rate and stocking method effects on sheep performance of oversown hill tussock grassland. Continuous grazing and rotational grazing with 1- or 3weekly grazing periods over the pasture growing season produced similar liveweight gains per hectare at low stocking rates. However, as mean stocking rates increased, the per hectare liveweight gain for the continuous grazed areas dropped to less than a quarter of that of the two rotationally grazed treatments in the sixth year. This reflects better pasture utilisation and regrowth. The liveweight gain was insignificantly greater from a 3-week than from a 1-week grazing cycle and was greatest at the moderate stocking rates.

With widely varying pasture growth between seasons and animal feed requirements similar throughout the year, pasture management aims to maintain a 'feed bank' ahead of stock requirement rather than to maximise pasture growth per se. Some grazing is needed to maintain the clover component of oversowings.

\section{Selection and breeding}

The medium to high heritability of wool traits means that genetic improvement can be made, e.g., the heritability of fleece weight is $0.1-0.6$, fibre diameter $0.1-0.7$, and other wool characteristics $0.2-0.8$. Note that selection can be for stock handling characteristics as well as product characterises, e.g., clear faces $(0.1-$
Table 3 Stock husbandry technologies for high country pastoral farming, their present use, potential impact and research support. Coding as in Table 1.

\begin{tabular}{|c|c|c|c|c|}
\hline \multirow[t]{2}{*}{ Technology } & \multirow[t]{2}{*}{ Use } & \multicolumn{3}{|c|}{ Potential Impact } \\
\hline & & Low & Mod. & High \\
\hline Feed budgeting & $U$ & & & $\mathrm{r}$ \\
\hline \multicolumn{5}{|c|}{$\begin{array}{l}\text { Sheep management/nutrition } \\
\text { wethers }\end{array}$} \\
\hline - target wool & $U$ & & & $r$ \\
\hline - target weights & $U$ & & & $\mathrm{R}$ \\
\hline - store sheep & UU & & $r$ & \\
\hline \multicolumn{5}{|l|}{ ewes } \\
\hline - target weights & UU & & & $\mathrm{R}$ \\
\hline - flushing & $U$ & & $\mathrm{R}$ & \\
\hline - Fecundin & $\mathrm{u}$ & $r$ & & \\
\hline - ram:ewe ratio & $U$ & $r$ & & \\
\hline - culling policy & UU & & $\mathrm{R}$ & \\
\hline - terminal sire & $U$ & & $\mathrm{R}$ & \\
\hline \multicolumn{5}{|l|}{ lambs } \\
\hline - timing & UU & & $r$ & \\
\hline - nutrition & UU & & & $\mathrm{R}$ \\
\hline - weaning & $U$ & & $r$ & \\
\hline $\begin{array}{l}\text { - sire referencing } \\
\text { hoggets }\end{array}$ & $\mathrm{u}$ & & $\mathrm{R}$ & \\
\hline - target weights & UU & & & $\mathrm{R}$ \\
\hline - 2T mating & $U$ & & $\mathrm{R}$ & \\
\hline \multicolumn{5}{|l|}{ Selection/breeding } \\
\hline culling policy & UU & & & $\mathrm{R}$ \\
\hline wool yields & UU & & & $\mathrm{R}$ \\
\hline fibre diameter & UU & & & RR \\
\hline wool characteristics & $U$ & & $r$ & \\
\hline teeth & UU & & $r$ & \\
\hline age & UU & & $r$ & \\
\hline ram selection & UU & & $\mathrm{R}$ & \\
\hline body conformation & UU & & $\mathrm{R}$ & \\
\hline Booroola gene & $\mathrm{u}$ & & $\mathrm{RR}$ & \\
\hline \multicolumn{5}{|l|}{ Shearing } \\
\hline timing & UU & & $r$ & \\
\hline method & UU & & $\mathrm{R}$ & \\
\hline wool classing & UU & & & $\mathrm{RR}$ \\
\hline objective measure & $\mathrm{u}$ & & $\mathrm{R}$ & \\
\hline \multicolumn{5}{|l|}{ Supplementation } \\
\hline protein & $\mathrm{u}$ & & $r$ & \\
\hline forage conservation & UU & & $\mathrm{R}$ & \\
\hline $\mathrm{Se}$ & UU & & & $\mathrm{RR}$ \\
\hline salt & UU & r & & \\
\hline S, N (urea) & $\mathrm{u}$ & & $r$ & \\
\hline 1 & $\mathrm{u}$ & $\mathrm{R}$ & & \\
\hline growth promoters & $U$ & & $\mathrm{R}$ & \\
\hline \multicolumn{5}{|l|}{ Animal health } \\
\hline anthelmetics & UU & & $\mathrm{RR}$ & \\
\hline footrot & UU & & $\mathrm{RR}$ & \\
\hline flystrike & UU & & $\mathrm{R}$ & \\
\hline ked & UU & & $\mathrm{R}$ & \\
\hline lice & UU & & $\mathrm{R}$ & \\
\hline itch mite & $U$ & & $r$ & \\
\hline abortion & $U$ & & $r$ & \\
\hline Johnes & $\mathrm{u}$ & & $r$ & \\
\hline clostridial & $\mathrm{u}$ & & $r$ & \\
\hline Tb - opossum & $U$ & & $r$ & \\
\hline \multicolumn{5}{|l|}{ Animal welfare/ethics } \\
\hline snow survival & UU & & & $\mathrm{R}$ \\
\hline disease & UU & & $\mathrm{R}$ & \\
\hline docking/tailing & UU & & $\mathrm{R}$ & \\
\hline mulesing & $U$ & & $r$ & \\
\hline
\end{tabular}


0.8 ) and legs to limit problems in snow. Other traits that are becoming more important as Merinos are farmed more intensively include resistance to footrot and internal parasites.

There is currently effort to identify genetic markers for heritable traits as a means for being able to change more quickly the genetic make-up of flocks. A marker for high fecundity (Booroola gene) has been found in Merino sheep. It will probably be more useful in meat sheep breeds.

\section{Wool classing}

Fleece preparation and wool classing are a crucial part of marketing, and technologies are well covered by research and training within the industry. There is increasing demand for objective measurement of wool characteristics as part of specialised marketing. This could be down to the level of individual sheep as in the Ultra Fine wool programme.

\section{Supplementation}

Selenium is the most universally deficient animal micronutrient administered in the high country, with 1-4 drenchings/year decreasing lamb mortality, and increasing growth rates, fecundity and wool growth of lambs, hoggets and ewes. Herbage iodine levels are low in inland unimproved pastures and spasmodically appear as stock goitre deficiencies. There are occasional reports of copper and cobalt deficiencies.

There is no general stock macro-nutrient deficiency requiring supplementation, though there are occasionally reports of suspected deficiencies during the early stages of pasture development. The spasmodic occurrence of "bowie" or "bent leg" in young stock is interpreted as protein deficiency at an earlier age rather than phosphate deficiency. While herbage sodium levels are known to be low, there has been no evidence of improved animal performance from the widespread use of salt blocks, though they are useful as a means of influencing grazing pattern.

\section{Animal health}

Control of external and internal parasites is an essential part of stock management. Control of parasites is either chemical (foot-rot, flystrike, ked, lice, and itch mite), or vaccine (Johne's disease, abortion, foot-rot and clostridial disease). Selection and breeding for genetic resistance to foot-rot and some internal parasites is possible. Herbage dietary effects on parasites has not been considered for the high country.

$\mathrm{Tb}$ is a problem of meat production and screening of cattle herds is now mandatory. Pest opossum control is for limiting $\mathrm{Tb}$ spread, rather than as a competitor for forage.

\section{Animal welfare and ethics}

Fly-strike appears to be an increasing problem and with it the adapting of the mulesing technique to combat it. Along with docking, castration, pizzle dropping, sheep stranding in snow, and images of rabbits dying are among the practicalities which are becoming increasingly important in consumers and general public perceptions which will increasingly affect market access. There is also the increasing public resistance to use of chemicals for animal health problems or drugs for (fertility and growth promoting drugs).

\section{Infra-structure and management}

Much of the capital value of farms is in their infrastructure and its components. Subdivision fencing and implements as the two components having a major impact on high country farm management (Table 4).

Table 4 Infra-structure and management technologies for high country pastoral farming, their present use, potential impact and research support. Coding as in Table 1.

\begin{tabular}{|c|c|c|c|c|}
\hline \multirow[t]{2}{*}{ Technology } & \multirow[t]{2}{*}{ Use } & \multicolumn{3}{|c|}{ Potential Impact } \\
\hline & & Low & Mod. & High \\
\hline \multicolumn{5}{|l|}{$\begin{array}{l}\text { Infra-structure } \\
\text { fencing }\end{array}$} \\
\hline - design & UU & & & $\mathrm{RR}$ \\
\hline $\begin{array}{l}\text { - paddock size/shape } \\
\text { stock handling facilities }\end{array}$ & $U$ & & $r$ & \\
\hline - yards & UU & & $r$ & \\
\hline - shearing & UU & & $\mathrm{R}$ & \\
\hline implements & UU & & & $\mathrm{RR}$ \\
\hline irrigation & $U$ & & $\mathrm{RR}$ & \\
\hline $\begin{array}{l}\text { stock water } \\
\text { buildings }\end{array}$ & UU & $\mathrm{R}$ & & \\
\hline - hay shed & UU & $\mathrm{R}$ & & \\
\hline - workshop & $U$ & & $\mathrm{r}$ & \\
\hline - implement storage & $U$ & $r$ & & \\
\hline roading and access & UU & & $\mathrm{R}$ & \\
\hline transport & UU & & $\mathrm{r}$ & \\
\hline living accommodation & UU & & $r$ & \\
\hline Management & & & & \\
\hline resource & UU & & RR & \\
\hline financial & UU & & & $\mathrm{R}$ \\
\hline time & $U$ & & $\mathrm{r}$ & \\
\hline labour & UU & & & $\mathrm{R}$ \\
\hline monitoring & $\mathrm{u}$ & $\mathrm{r}$ & & \\
\hline support systems & $\mathrm{u}$ & & $r$ & \\
\hline
\end{tabular}

Labour is a large component of high country farming expense and there is a trend, as in other farming systems, to substitute machinery for labour. The nature of terrain and the type of farming in the high country probably limit the extent to which this can be done. But the very scale of high country runs may make some options economic in the high country but not be in other situations, e.g., the developing technology of helicopter mustering. 
Development of irrigation is included under infrastructure because of its generally initial high cost and present only moderate use.

Subdivision fencing requires a compromise between desirability and cost. From an agronomic perspective of pasture growth and animal control, the variability of land classes and environment within a high country run should imply a higher degree of subdivision than in other environments. But with the lower productivity of high country pastures, up to 20 times the length of fencing per sheep may be needed to enclose the same feed supply on an unimproved high country run as on a improved lowland pasture.

Actual and potential impact of financial and labour management are high.

\section{Discussion}

The paper has attempted to list the various aspects and technologies that are considered in high country farming, their present use, potential impact, and the degree to which they are supported by known investigations. It is hoped these will aid in determining where changes are possible and/or desirable. Readers may not agree with our various assessments. But if it prompts further consideration of the relative impact of the different technologies on total run success, then the paper will have served its purpose.
It became apparent in making these assessment that many of the simple procedures, practices or techniques of today had a complex development history, some known, some unknown. It also became apparent for the need to re-examine the basis of some of the practices in changing situations, e.g., the lime coating of seed rather than liming of pastures to ensure rhizobia infection; the use of salt licks; the requirement for stock water for well-fed stock when there are reports of failure to observe drinking during three summer observations of sheep on semi-arid tussock grassland, or the existence of successful third generation flocks that have never seen water.

This raises the question in the present era of userpays, of where new high country technologies will be developed. As indicated earlier, most will come directly from the practitioners - the farmers, e.g., breed societies and Merino New Zealand. For physical saleable products or smaller tractable problems with low development costs, then private industry is probably the most efficient. The development of techniques or procedures that are not saleable as such (e.g., shearing technique, grazing management techniques) need industry-wide and/or government funding to develop and promote. The less tractable problems with high time or monetary costs, like sustainability, and rabbit and hieracium control, need industry-wide and/or government support. 